\title{
Comparison of disinfectants for drinking water: chlorine gas vs. on-site generated chlorine
}

\author{
Yonkyu Choi ${ }^{\dagger}$, Seung-Heon Byun, Hyun-Jung Jang, Sang-Eun Kim, Young-june Choi \\ Seoul Water Institute, 716-10, Cheonho-daero, Gwangjin-gu, Seoul, Korea, 04981
}

\begin{abstract}
The feasibility of on-site generated chlorine (OSG chlorine) as an alternative disinfectant to chlorine gas was evaluated in terms of total organic carbon (TOC) removal, disinfection efficiency, biofilm control, disinfection by-products (DBPs) formation, chlorine decay rate, and volatility. Chlorine gas decreased the $\mathrm{pH}$ of the treated water by -0.1 per $\mathrm{mg} / \mathrm{L}$ of free available chlorine (FAC) while OSG chlorine increased the $\mathrm{pH}$ by +0.06 per $\mathrm{mg} / \mathrm{L}$. OSG chlorine with more hypochlorite ion $\left(\mathrm{OCl}^{-}\right)$at higher $\mathrm{pH}$ was less effective in the inactivation of suspended bacteria and TOC removal but remained in the distribution system longer and controlled biofilm formation more effectively than chlorine gas. The DBPs formation by OSG chlorine was not significantly different from that by chlorine gas except for the reduction of Haloacetonitriles. Hypochlorous acid (HOCl)

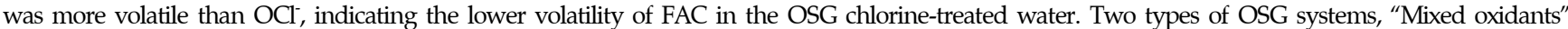
and OSG hypochlorite, did not show any significant difference in disinfection, DBPs formation, and chlorine decay rate (paired $\mathrm{t}$-test, $\mathrm{p}=0.40$, $0.11 \sim 0.70,>0.42$ ). A significant synergy effect by oxidants other than FAC cannot be expected in the use of "mixed oxidants" at a water treatment plant.
\end{abstract}

Keywords: Chlorine gas, DBPs, Disinfection, Mixed oxidants, On-site generated chlorine, Sodium hypochlorite

\section{Introduction}

Chlorine has been widely used for drinking water disinfection since the early $20^{\text {th }}$ century because it is cost-effective, and it can inactivate a range of pathogenic microorganisms and maintain disinfection properties in the distribution system [1, 2]. A couple of different chemicals are used for chlorine disinfection, e.g., chlorine gas (liquid chlorine), commercial sodium hypochlorite $(\mathrm{NaOCl})$ solution, and calcium hypochlorite $\left(\mathrm{Ca}(\mathrm{ClO})_{2}\right)$ tablets [1-3]. When all of these chemicals are added to water, they form free available chlorine (FAC), i.e., hypochlorous acid (HOCl) and hypochlorite ion $\left(\mathrm{OCl}^{-}\right)$, which can inactivate microorganisms and oxidize organic matter [1, 3].

Chlorine gas is economical and operationally reliable, but it is hard to handle and requires special training and facilities for safety due to its toxicity and explosive nature [1]. Safety concerns and regulations related to the use of chlorine gas have sparked interest in alternative chemicals for chlorine gas [1, 4]. One option is sodium hypochlorite, known as liquid bleach, which contains about $5 \sim 15 \%$ FAC $[1,3]$. Although using sodium hypochlorite solution eliminates the danger of a toxic gas leak, it is also hard to handle. It is very corrosive to most metals and causes scaling and clogging of pipes and valves due to crystallization [1]. Sodium hypochlorite degrades over time due to sunlight and high temperature and results in a decrease of FAC concentration, so periodic monitoring and adjustment of feed rates are required [1, 3, 5, 6]. In addition, the decomposition of sodium hypochlorite produces other harmful inorganic by-products such as chlorate $\left(\mathrm{ClO}_{3}^{-}\right)$ and perchlorate $\left(\mathrm{ClO}_{4}^{-}\right)$, which are not formed by chlorine gas $[1,5,6]$.

On-site generation (OSG) of chlorine can be another alternative for chlorine disinfection. The OSG system usually produces non-hazardous chlorine solutions with low FAC concentration (< $0.8 \%$ ) by the electrolysis of brine [5]. OSG chlorine is considered to be relatively safe, and it's operation does not require special facility and training $[2,5]$. OSG chlorine eliminates transportation costs since it does not require any transportation, but it can be stored on-site for a period of 1 3 d [5, 7].

There are two kinds of OSG systems: sodium hypochlorite generator and "mixed oxidants" generator $[4,7,8]$. Low-strength OSG
This is an Open Access article distributed under the terms of the Creative Commons Attribution Non-Commercial License (http://creativecommons.org/licenses/by-nc/3.0/) which permits unrestricted non-commercial use, distribution, and reproduction in any medium, provided the original work is properly cited.

Copyright (C) 2022 Korean Society of Environmental Engineers
Received September 27, 2020 Accepted January 17, 2021

${ }^{\dagger}$ Corresponding author

E-mail: pavian@seoul.go.kr

Tel: +82-2-3146-1782 Fax: +82-2-3146-1798

ORCID: 0000-0003-2608-9990 
which produces $0.4 \sim 0.8 \%$ by weight sodium hypochlorite is widely used in the drinking water system even though high-strength OSG, which produces $12 \sim 15 \%$ by weight sodium hypochlorite, was developed recently [9]. On the other hand, "mixed oxidants" generator is known for producing ozone, chlorine dioxide, and hydrogen peroxide as well as chlorine [4, 6, 8]. Based from previously done studies [4, 10-13], it was reported that "mixed oxidants" were more effective than chlorine in inactivating microorganisms, removing biofilm, and reducing DBP formation and chlorinous odor. Still, the exact composition and concentration of the produced oxidants in the "mixed oxidants" remain unclear [6, 14]. Moreover, in most previous studies [10-12], commercial sodium hypochlorite solution was used as chlorine disinfectant instead of chlorine gas. Although sodium hypochlorite has the same functions as chlorine gas in terms of formation of $\mathrm{HOCl}$ and $\mathrm{OCl}^{-}$in water, chlorine gas which acts as an acid $(\mathrm{pH}<2)$ decreases the water $\mathrm{pH}$ while sodium hypochlorite, which tends to be alkaline ( $\mathrm{pH}$ 11 13), increases the $\mathrm{pH}$ of water $[1,3,6]$. HOCl is a much stronger and more reactive oxidant than $\mathrm{OCl}^{-}$, and the distribution of $\mathrm{HOCl}$ and $\mathrm{OCl}^{-}$ is determined by $\mathrm{pH}$ : The ratio of $\mathrm{HOCl} / \mathrm{OCl}^{-}$is equal at about $\mathrm{pH} 7.5$ and increases with decreasing $\mathrm{pH}$ under typical drinking water treatment conditions $[2,6,15]$. Thus, the disinfection efficiency of chlorine depends on $\mathrm{pH}$ and can be more effective at lower $\mathrm{pH}[2,6]$.

Therefore, the results of previous studies with commercial sodium hypochlorite solution are hardly appropriate for evaluating the feasibility of OSG chlorine as an alternative disinfectant to the chlorine gas used in the water treatment plant. In addition, previous studies have focused on the disinfection efficiency and DBPs formation, but there is a need to evaluate other properties such as TOC removal, biofilm control, and residual effect to determine the feasibility of OSG chlorine in a full-scale drinking water treatment plant.

In this study, therefore, the chlorine stock solution made by dissolving chlorine gas in ultrapure water was used as chlorine disinfectant. The effect of chlorine gas was compared with that of on-site generated sodium hypochlorite (OSG hypochlorite) and "mixed oxidants" in terms of TOC removal, disinfection efficiency, biofilm control, DBPs formation, residual effect, and volatility. In addition, the effects of oxidants other than FAC in the "mixed oxidants" were investigated.

\section{Materials and Methods}

\subsection{Preparation of Disinfectants and Samples}

Chlorine gas was dissolved in ultrapure water to make chlorine stock solution (more than 2,000 mg/L as FAC). On-site generated chlorine was made by the electrolysis of brine. To compare the performance of "mixed oxidants" and OSG hypochlorite, small-scale "mixed oxidants" generator (OSG-A) and on-site hypochlorite generator (OSG-B) were used, producing stock solution with about $0.1 \%$ of FAC. The OSG chlorine was produced each day just before the experiments to prevent changes of possible oxidants in the "mixed oxidants". In addition, the electrolyzed solution was sampled from the five full-scale OSG generators that were being operated in water treatment plants including 4 OSG hypochlorites (about $0.8 \%$ FAC) and a "mixed oxidants" (about 0.4\% FAC). Considering the hydraulic residence time in a typical water treatment plant, the electrolyzed solution was sampled in situ and stored in the lab at room temperature for one day before use.

Two types of water samples were investigated: 1) pre-chlorinated sand-filtered water (SF) collected from a water treatment plant in Seoul, and 2) glass fiber-filtered water $(\mathrm{GF} / \mathrm{F})$ prepared in the laboratory through the Jar test (coagulation-sedimentation) and filtration with GF/F filter (Whatman) using Han River water to exclude the effect of the pre-chlorination process. Chlorine gas and OSG chlorines were added to the sample waters to get the same concentration of FAC. The $\mathrm{pH}$ and residual FAC concentration of the electrolyzed solution and the treated water were measured by $\mathrm{pH}$ meter (Orion, 420A) and Hach pocket chlorine colorimeter, respectively.

\subsection{TOC Removal}

Chlorine gas and the five full-scale OSG chlorines were added to the processed glass fiber-filtered water (TOC $1.41 \mathrm{mg} / \mathrm{L}$ ) at 1 and $3 \mathrm{mg} / \mathrm{L}$ as FAC, respectively. $1 \mathrm{mg} / \mathrm{L}$ of disinfectants was added to evaluate the TOC removal per unit chlorine concentration. However, $1 \mathrm{mg} / \mathrm{L}$ of disinfectants was depleted due to the high TOC concentration in the water samples. Thus, a sufficient amount of disinfectants $(3 \mathrm{mg} / \mathrm{L})$ was added to have residual chlorine after reacting for $48 \mathrm{~h}$.

Water samples were decanted into $125 \mathrm{~mL}$ glass bottles without headspace and sealed with Teflon-lined caps. The samples were reacted in an incubator at $25^{\circ} \mathrm{C}$ for $48 \mathrm{~h}$, and the TOC concentration of the samples before and after $48 \mathrm{~h}$ was measured using a TOC analyzer (Ionic, Sivers 820).

To compare TOC removal by the disinfectants applied for post-chlorination, chlorine gas and two small-scale OSG chlorines were added to the pre-chlorinated sand-filtered water at $2 \mathrm{mg} / \mathrm{L}$ as FAC. The sand-filtered water had lower chlorine demand than the glass fiber-filter effluent since it was already treated by pre-chlorination. Thus, the residual chlorine was detected after reaction for $48 \mathrm{~h}$.

The TOC concentration was measured before and after the 48 $\mathrm{h}$ reaction at $25^{\circ} \mathrm{C}$. This experiment was conducted 5 times considering the seasonal change of water quality of sand-filtered water.

\subsection{Disinfection}

Bacillus subtilis spores (ATCC 6633), a chlorine-resistant microorganism, were used for comparing the disinfection efficiency of chlorine gas and two small-scale OSG chlorines including a "mixed oxidants" system.

Two different disinfection tests were conducted to confirm the disinfection efficiency of oxidants other than FAC in the OSG chlorine, i.e., (1) under constant $\mathrm{pH}$-controlled conditions and (2) under uncontrolled pH conditions. Double-walled 3-neck culture bottles were used as disinfection reactors. The water temperatures in the reactors were kept constant by water bath circulators. For the test under controlled $\mathrm{pH}$ conditions, $B$. subtilis spores were inoculated into $0.001 \mathrm{M}$ phosphate-buffered saline (PBS) to make $10^{5} \mathrm{CFU} / \mathrm{mL}$, and the water temperature was maintained at $5^{\circ} \mathrm{C}$ 
to compare the disinfection efficiency by disinfectants under winter conditions wherein disinfection efficiency is lowest. Then, $6 \mathrm{mg} / \mathrm{L}$ as FAC of the disinfectants was injected into the reactors, and the $\mathrm{pH}$ of each sample with disinfectant was adjusted to 7.2 with $0.1 \mathrm{~N} \mathrm{HCl}$ and $\mathrm{NaOH}$ when necessary.

On the other hand, to simulate the conditions of typical water treatment plants, the sand-filtered water was sterilized, and $B$. subtilis spores were inoculated into the sterilized sand-filtered water to make $10^{5} \mathrm{CFU} / \mathrm{mL}$. With the $\mathrm{pH}$ uncontrolled, the same concentration of disinfectants of $2 \mathrm{mg} / \mathrm{L}$ as FAC was added to the samples. The water temperature was kept relatively high at $20^{\circ} \mathrm{C}$ for a clear comparison of disinfection efficiency even with low FAC concentration. The sample waters in the reactors were mixed constantly and sampled by time to measure the concentration of residual FAC and the number of viable $B$. subtilis spores. The disinfection efficiency was compared as a CT value for the same log inactivation, with $\mathrm{C}$ being the time-averaged concentration of FAC $(\mathrm{mg} / \mathrm{L})$ and $\mathrm{T}$ being the contact time (min). To determine the CT values, residual FAC concentration was regressed nonlinearly according to the exponential decay model $\left(\mathrm{y}=\mathrm{a} e^{-b x}+c e^{-d x}, \mathrm{R}^{2}>0.98\right)$ using SigmaPlot. The CT value was calculated by integrating the regressed results by time. To explain the kinetics of the inactivation of $B$. subtilis spores, the delayed Chick-Watson model was used [12].

Cultivation and analyses of $B$. subtilis spores were carried out according to the procedure described in the EPA UV disinfection guidance manual [16] with a few modifications (B. subtilis was cultivated for $10 \mathrm{~d}$ to form a high concentration of spore). Residual FAC was quenched using sterile sodium thiosulfate (final concentration of $0.01 \%$ ) from the sampled water by time to stop the inactivation of $B$. subtilis spores. Viable spores were enumerated by the pour plate method with plate count agar (Difco). The plates were incubated at $37^{\circ} \mathrm{C}$ for $48 \mathrm{~h}$, and the colonies on the plates were then counted.

\subsection{Disinfection of suspended bacteria and biofilm control}

CDC Biofilm Reactors (Biosurface Technologies) with small circular sample coupons were installed to compare disinfection efficiency and biofilm control by chlorine gas and OSG-A ("mixed oxidants") (Fig. 1). The influent of the reactors was tap water removed residual chlorine by granular activated carbon (GAC) filter. The chlorine-free tap water was stored in the reservoir $(50 \mathrm{~L})$ before filling the reactors.

Stainless steel (STS) and polyethylene (PE) sample coupons were installed in each reactor, and chlorine gas and OSG chlorine were added to the reactors of $350 \mathrm{~mL}$. The residual FAC concentration in the reactors was maintained at 1.0 and $0.5 \mathrm{mg} / \mathrm{L}$ to simulate the conditions in the water treatment plant and distribution system. A peristaltic pump was used to maintain the flow of the samples and disinfectants at $11.2 \mathrm{~mL} / \mathrm{min}$ and $0.5 \mathrm{~mL} / \mathrm{min}$, respectively, which corresponded to the hydraulic residence time of $30 \mathrm{~min}$ (condition recommended by the manufacturer of the CDC reactor). The concentration of disinfectant in the reactor was kept constant by controlling the concentration of the stock solution of disinfectants according to the changes in water quality and temperature. The stock solution was replaced every 2 3 d considering the storage time of OSG chlorines in a typical water treatment plant. A magnetic stirrer was operated at $100 \mathrm{rpm}$ to simulate the shear stress in the pipe.

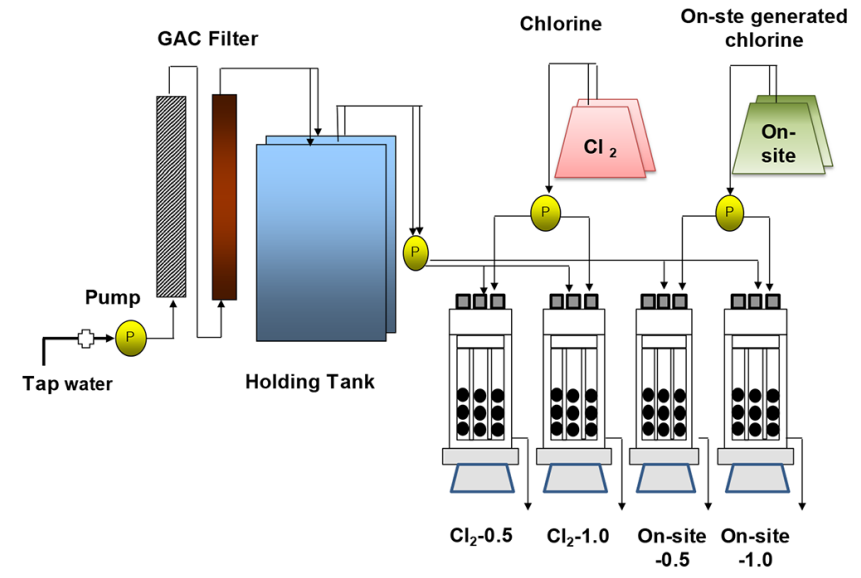

Fig. 1. Flow diagram of $\mathrm{CDC}$ biofilm reactors.

The residual FAC, $\mathrm{pH}$, TOC, suspended bacteria in the influent and effluent, and biofilm formed on the coupons were monitored. The residual FAC, pH, and TOC were measured with Hach pocket chlorine colorimeters, pH meter (Thermo 420A), and TOC analyzer (Ionic, Sivers 820), respectively. The suspended bacteria were analyzed more than 5 times a week and enumerated by the pour plate method after serial dilution and incubation for $7 \mathrm{~d}$ at $28 \pm 1.0^{\circ} \mathrm{C}$ on R2A agar (Difco) to form easily visible colonies. As the GAC filtered tap water was stored in a different tank before being introduced to the reactors, the number of suspended bacteria in each influent of the reactors was different. To compare the inactivation of suspended bacteria by disinfectants, data were collected and averaged for $27 \mathrm{~d}$ when the number of suspended bacteria in the influent of the reactors was similar.

The number of bacteria in biofilm was analyzed 5 times at an interval of 10 15 d during the experiment. Biofilm was scraped from the surface of the coupons with a sterilized scraper and collected into a sterilized conical tube with $20 \mathrm{~mL}$ of $0.01 \mathrm{M}$ PBS and sterile sodium thiosulfate. The biofilm sample was treated with ultrasound for $30 \mathrm{~s}$ and dispersed completely by vortex mixing. The treated sample was spread on the plate of R2A agar (Difco) after serial dilution. The inoculated plates were incubated at $28 \pm 1.0^{\circ} \mathrm{C}$ for $7 \mathrm{~d}$. The number of bacteria per $\mathrm{mL}$ $(\mathrm{CFU} / \mathrm{mL})$ was converted into the number of bacteria per unit area $\left(\mathrm{CFU} / \mathrm{cm}^{2}\right)$.

\subsection{Disinfection By-Products Formation}

To compare disinfection by-products (DBPs) formation by chlorine gas and OSG chlorine, the same concentration of disinfectants was injected to maintain residual FAC above $0.5 \mathrm{mg} / \mathrm{L}$ after 48 $\mathrm{h}$ at $25^{\circ} \mathrm{C}$, i.e., $2 \sim 3$ times more than the concentration of TOC in sand-filtered water (for two small-scale generators) and processed glass fiber-filtered water (for five full-scale generators). The experiment for two small-scale OSGs was carried out $3 \sim 5$ times considering the seasonal change of water quality of sand-filtered water.

Water samples were decanted into $125 \mathrm{~mL}$ glass bottles with organic materials removed by baking at $550^{\circ} \mathrm{C}$ for $2 \mathrm{~h}$ without headspace, and the bottles were sealed with Teflon-lined caps. The samples were reacted in the incubator at $25^{\circ} \mathrm{C}$ for $48 \mathrm{~h}$. After 
the reaction, residual chlorine was removed with quenching agents to prevent further DBPs formation. In the case of using sand-filtered water as samples, DBPs formation was evaluated by subtracting the DBPs' concentrations before adding the disinfectants from the concentrations of DBPs after $48 \mathrm{~h}$ reaction with the disinfectants, since some DBPs formed by pre-chlorination were present in the sand-filtered water.

Trihalomethanes (THMs) were analyzed by the purge and trap method with GC/MSD (Agilent 6890N/ Agilent 5975) according to US EPA 524.2 [17]. Haloacetic acids (HAAs) were analyzed by GC/ECD (Agilent 6890N) after liquid-liquid extraction according to US EPA 552.3 [18]. The sum of dichloroacetic acid (DCAA) and trichloroacetic acid (TCAA) was determined as HAAs. Haloacetonitriles (HANs), haloketones (HKs), chloral hydrate $(\mathrm{CH})$, and chloropicrin (CP) were also analyzed by GC/ECD (Varian CP-3800) after liquid-liquid extraction according to US EPA 551.1 [19]. HANs included trichloroacetonitrile (TCAN), dichloroacetonitrile (DCAN), and dibromoacetonitrile (DBAN). HKs were the sum of 1,1-dichloro-2-propanone (DCP) and 1,1,1-trichloro-2-propanone (TCP).

\subsection{Chlorine Decay Rate and Volatility}

$2 \mathrm{~L}$ volumetric flasks were filled with ultrapure water and the sand-filtered water. $2 \mathrm{mg} / \mathrm{L}$ as FAC of chlorine gas and two small-scale OSG chlorines were added to ultrapure water and to the sample waters and mixed shortly and vigorously using a magnetic stirrer to minimize changes in the FAC concentration. The chlorinated sample water was decanted into eleven $125 \mathrm{~mL}$ pre-baked glass bottles without headspace and sealed with Teflon-lined caps. The samples were reacted in the incubator at $25^{\circ} \mathrm{C}$ for $96 \sim 145 \mathrm{~h}$ and taken out by time to measure the residual FAC. The concentration of FAC in ultrapure water at the beginning was defined as the initial concentration injected. Chlorine demand was calculated by subtracting the residual FAC concentration after 2, 24, $48 \mathrm{~h}$ from the initial FAC concentration. The chlorine decay rate was estimated by the first-order decay model [20]. In this study, two separate chlorine decay rates were calculated, i.e., rapid chlorine decay rate $\left(\mathrm{K}_{1}\right)$ for the first $6 \mathrm{~h}$ and slow chlorine decay rate $\left(K_{2}\right)$ after $6 \mathrm{~h}$.

$$
C_{t}=C_{0} e^{(-\mathrm{kt})}
$$

Where $C_{t}=$ chlorine concentration $(\mathrm{mg} / \mathrm{L})$ at time $\mathrm{t} ; C_{0}=$ initial chlorine concentration $(\mathrm{mg} / \mathrm{L}) ; \mathrm{k}=$ decay constant $\left(\mathrm{h}^{-1}\right)$; t: residence time (h).

To investigate the volatility of disinfectants, $0.01 \mathrm{M}$ PBS was used as water sample to prevent the change in $\mathrm{pH}$ due to the dissolution of $\mathrm{CO}_{2}$ in the air to ultrapure water. $2 \mathrm{mg} / \mathrm{L}$ as FAC of chlorine gas and OSG chlorine were added to ultrapure water and PBS, and the $\mathrm{pH}$ of the PBS was controlled to 7.5, below 5, and over 10 using $0.1 \mathrm{~N} \mathrm{HCl}$ and $0.1 \mathrm{~N} \mathrm{NaOH}$ to study the effect of $\mathrm{HOCl} / \mathrm{OCl}^{-}$ratio on volatility. The concentration of $\mathrm{FAC}$ in ultrapure water was defined as the initial concentration injected. The chlorinated PBS sample was put into wide-mouth glass bottles with and without cap and was allowed to stand at room temperature $\left(22^{\circ} \mathrm{C}\right)$ for $28 \mathrm{~h}$. The residual FAC concentration was measured by time. There was an initial FAC demand in PBS because inorganic substances such as phosphate could react with disinfectants although there was little organic material to react. FAC demand was observed during the first 10 minutes of each run, and there was insignificant change in residual FAC concentration in the closed bottle without headspace for $28 \mathrm{~h}$. Thus, volatility could be calculated by subtracting the residual FAC concentration in the opened bottle from the FAC concentration in the closed bottle at $10 \mathrm{~min}$ after adding disinfectants to PBS.

\section{Results and Discussion}

\section{1. $\mathrm{pH}$}

The $\mathrm{pH}$ of the chlorine stock solution ranged from 1.7 to 3.4 while that of the small-scale OSG chlorines (FAC concentration: 0.1\%) ranged from 8.3 to 9.2 . The $\mathrm{pH}$ of the full-scale OSG chlorines (FAC concentration: $0.4 \sim 0.8 \%$ ) was within the range of 9.2 9.7. The $\mathrm{pH}$ of OSG chlorine stock solution increased with the FAC concentration produced by the electrolysis of brine. For commercial sodium hypochlorite solution, the $\mathrm{pH}$ of $5 \%$ solution is about 11 , and more concentrated solutions $(10 \sim 15 \%)$ have higher $\mathrm{pH}$ of about 13. [3]

The $\mathrm{pH}$ of sand-filtered water decreased with an increasing dose of chlorine gas (-0.1 per mg/L FAC, $\left.\mathrm{R}^{2}=0.98\right)$ but increased with an increasing dose of small-scale OSG chlorine $(+0.06$ per $\mathrm{mg} / \mathrm{L}$ FAC, $\mathrm{R}^{2}=0.95$ ) (Fig. S1). With the addition of $3 \mathrm{mg} / \mathrm{L}$ as FAC, the $\mathrm{pH}$ of glass fiber-filtered water treated with chlorine gas and five full-scale OSG chlorines was 7.5 and 7.8, respectively. Chlorine gas acts as an acid, and it can decrease the $\mathrm{pH}$ of water, whereas OSG chlorine tends to be alkaline and increases the $\mathrm{pH}$ of water $[1,3,6]$.

The $\mathrm{pH}$ increase per unit FAC concentration in water can vary depending on the $\mathrm{pH}$ and injection volume of OSG chlorine stock solution. The FAC concentration in the stock solution decreases over time during storage due to sunlight and high temperature, and older OSG chlorine solution contains less FAC [3, 5]. With longer storage period, the injection volume of OSG chlorine will increase to meet the target FAC concentration in water, and the $\mathrm{pH}$ of the water will be higher. Fortunately, however, no significant change is expected in the OSG chlorine system in a typical water treatment plant due to the short storage period of 1-3 $\mathrm{d}$.

\subsection{TOC Removal}

TOC removal efficiencies were compared in the processed glass fiber-filtered water (TOC: $1.41 \mathrm{mg} / \mathrm{L}$ ) between chlorine gas and the five full-scale OSG chlorines with 1 and $3 \mathrm{mg} / \mathrm{L}$ as FAC, respectively.

The average TOC removals with $1 \mathrm{mg} / \mathrm{L}$ of disinfectants were not significantly different (ANOVA, $p=0.99$ ), i.e., $9.9 \%$ for chlorine gas (TOC: $1.21 \sim 1.33 \mathrm{mg} / \mathrm{L}$ ) and $9.6 \%$ for the OSG chlorines (TOC: $1.24 \sim 1.31 \mathrm{mg} / \mathrm{L}$ ) (Fig. S2). When $3 \mathrm{mg} / \mathrm{L}$ of disinfectants were added, however, chlorine gas could remove TOC more effectively compared to the OSG chlorines (ANOVA, $\mathrm{p}=0.01$ ). The average TOC removal was 19.5\% (TOC: 1.13 1.14 mg/L) for chlorine gas and 14.0\% (TOC: $1.19 \sim 1.25 \mathrm{mg} / \mathrm{L}$ ) for five OSG chlorines. Residual 
chlorine was not detected in the samples treated with $1 \mathrm{mg} / \mathrm{L}$ of disinfectants, but it was detected in the samples after the reaction with $3 \mathrm{mg} / \mathrm{L}$ of disinfectants. With the $3 \mathrm{mg} / \mathrm{L}$ of disinfectants, FAC consumption with chlorine gas was higher than that with OSG chlorines (refer to Section 3.6). TOC removal per FAC consumption was $10.4 \%$ per mg/L for chlorine gas and 9.6 (8.2 10.8)\% per $\mathrm{mg} / \mathrm{L}$ for OSG chlorines, which were similar to the TOC removals by $1 \mathrm{mg} / \mathrm{L}$ of disinfectants. These results indicate that TOC removal is related to FAC consumption rather than FAC dose, and that the higher TOC removal by chlorine gas could be attributed to the higher reactivity (consumption) of chlorine gas compared to OSG chlorines. $\mathrm{HOCl}$ is more reactive and stronger than $\mathrm{OCl}^{-}$[15], and chlorine gas-treated water with lower $\mathrm{pH}$ could contain a higher amount of HOCl than OSG chlorine-treated water. Thus, TOC could be removed more effectively by the more active reaction with $\mathrm{HOCl}$ in the chlorine gas-treated water. On the other hand, $1 \mathrm{mg} / \mathrm{L}$ of disinfectants was not enough to oxidize organic compounds in the water, and both disinfectants were depleted during the reaction. Thus, the TOC removals by chlorine gas and OSG chlorines could be similar due to the similar FAC consumption.

To study the efficiency of TOC removal when applying disinfectants for post-chlorination, $2 \mathrm{mg} / \mathrm{L}$ as FAC of chlorine gas and two small-scale OSG chlorines were added to the sand-filtered water. The TOC concentrations of the sand-filtered waters were in the range of $0.79 \sim 1.24 \mathrm{mg} / \mathrm{L}$, and there was insignificant removal of TOC by both chlorine gas and OSG chlorines (paired t-test, $p=0.11 \sim 0.48$ ) (Fig. S2). The sand-filtered water was already treated with pre-chlorination, and most of the organic materials could have reacted with FAC in the process. As the remaining organic materials might be less reactive with FAC, there would be no further TOC removal.

\subsection{Disinfection of Suspended Bacteria}

Disinfection efficiency was evaluated for chlorine gas and two small-scale OSG chlorines at $5^{\circ} \mathrm{C}$ and $\mathrm{pH} 7.2$ after suspending B. subtilis spores in PBS. The disinfection efficiency (log inactivation) was similar for each disinfectant tested. After the lag phase at the beginning, the inactivation efficiency increased linearly with the CT value, and the log inactivation at the same CT value by three disinfectants did not show significant difference at $95 \%$ confidence intervals, i.e., not only for chlorine gas and OSG chlorines (paired t-test, $\mathrm{p}=0.07 \sim 0.11$ ) but also for "mixed oxidants" and OSG hypochlorite (paired t-test, $\mathrm{p}=0.40$ ) (Fig. 2). The CT demands for chlorine gas and two OSG chlorines were also very similar, i.e., $460 \sim 469 \mathrm{mg} \cdot \mathrm{min} / \mathrm{L}$ for $1 \log (90 \%)$ inactivation and 644 671 $\mathrm{mg} \cdot \mathrm{min} / \mathrm{L}$ for $2 \log$ (99\%) inactivation (Table 1). The

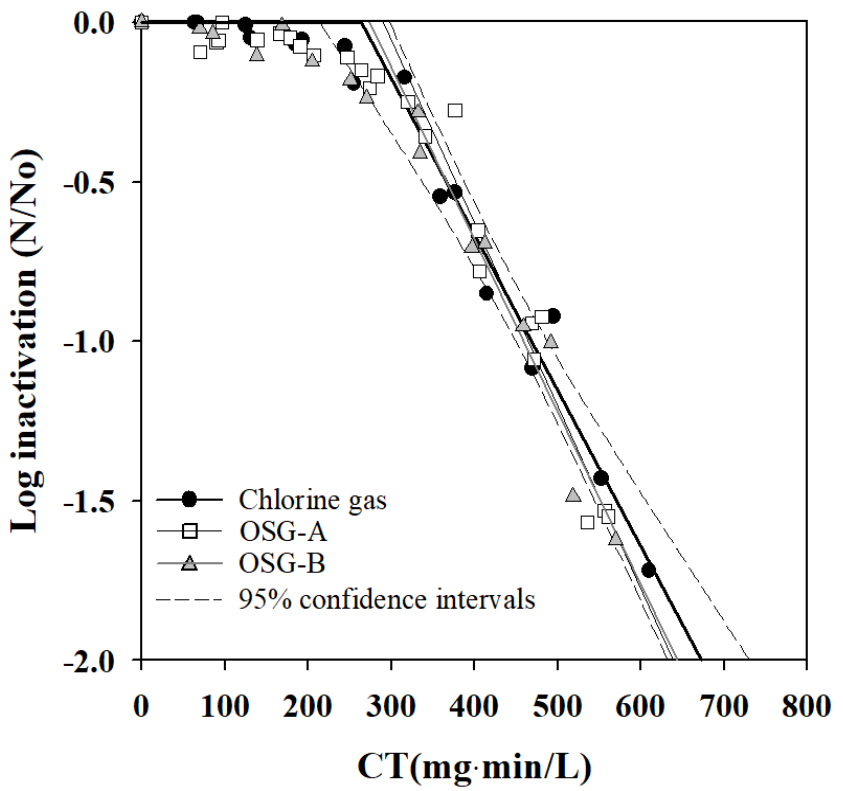

Fig. 2. Log inactivation of Bacillus spore by chlorine gas and two small-scale OSG chlorines with CT. (Temp $5^{\circ} \mathrm{C}, \mathrm{pH}$ 7.2)

improvement of inactivation efficiency by other oxidants such as ozone and chlorine dioxide was not observed in both "mixed oxidants" and OSG hypochlorite.

Many previous studies reported that the "mixed oxidants" could effectively inactivate bacteria and viruses in a very short time [10], and that it was more effective than chlorine in the inactivation of chlorine-resistant microorganisms such as Cryptosporidium parvum oocyst, Clostridium perfringens spores, and Bacillus subtilis spores [10-12, 21]. Son et al. (2005) also reported that mechanically mixed oxidants of $\mathrm{Cl}_{2} / \mathrm{O}_{3}, \mathrm{Cl}_{2} / \mathrm{ClO}_{2}$, and $\mathrm{Cl}_{2} / \mathrm{ClO}_{2}{ }^{-}$showed higher disinfection efficiency than $\mathrm{Cl}_{2}$ alone [22]. These observations suggest that there are oxidants other than FAC in the "mixed oxidants". The formation of $\mathrm{O}_{3}, \mathrm{H}_{2} \mathrm{O}_{2}, \mathrm{ClO}_{2}$, and $\mathrm{OH}$ radical by the electrolysis of brine was experimentally demonstrated [23, 24], and Tien and Luu (2020) reported that the generation of other oxidants such as $\mathrm{OH}$ radical was dependent on the material of the electrode [25]. Nonetheless, there has been a lot of controversy over the formation of oxidants other than FAC in the "mixed oxidants" system. Gordon et al. (2002) reported that they could not detect $\mathrm{O}_{3}, \mathrm{ClO}_{2}$, and $\mathrm{H}_{2} \mathrm{O}_{2}$ in the "mixed oxidants" system, and FAC was the primary oxidant resulting from brine electrolysis [14]. Such discrepancies in reports may be attributable to the differences in the devices used for the electrolysis of brine and time difference

Table 1. CT Demand of Chlorine Gas and Two Small-Scale OSG Chlorines for Each Log Inactivation of Bacillus Subtilis Spore (mg min/L)

\begin{tabular}{|c|c|c|c|c|c|c|c|}
\hline & & \multicolumn{3}{|c|}{ pH controlled } & \multicolumn{3}{|c|}{ pH uncontrolled } \\
\hline & & Chlorine gas & OSG-A & OSG-B & Chlorine gas & OSG-A & OSG-B \\
\hline \multirow{2}{*}{ Log Inactivation } & 1 & 467 & 469 & 460 & $239-251$ & 381 & 327 \\
\hline & 2 & 671 & 644 & 645 & $330-366$ & 535 & 549 \\
\hline \multirow[t]{2}{*}{$\mathrm{pH}$} & & 7.2 & 7.2 & 7.2 & 7.2-7.6 & 7.8 & 7.8 \\
\hline & & \multicolumn{3}{|c|}{ Matrix: PBS, Temperature: $5^{\circ} \mathrm{C}$} & \multicolumn{3}{|c|}{ Matrix: sand-filtered water, Temperature: $20^{\circ} \mathrm{C}$} \\
\hline
\end{tabular}


between disinfectant formation and use. The "mixed oxidants" generators used for the previous studies were portable or bench-scale devices, and the oxidants were generated in the lab just before the experiments [10-12]. On the other hand, the "mixed oxidants" used for this study came from the full-scale generators installed and used in water treatment plants. Although freshly generated "mixed oxidants" was used to minimize the effect of time lag, it took about $3 \mathrm{~h}$ to use in the lab after generating the "mixed oxidants". It might be impossible for other oxidants such as $\mathrm{O}_{3}$, $\mathrm{ClO}_{2}$, and $\mathrm{H}_{2} \mathrm{O}_{2}$ to remain under this condition, if any. $\mathrm{O}_{3}$ is very unstable in water and undergoes the auto-decomposition process in alkaline conditions; $\mathrm{ClO}_{2}$ is very volatile and degrades into chlorite and chlorate at high $\mathrm{pH}$ [6]. $\mathrm{O}_{3}$ reacts very fast, i.e., millisecond $\sim$ second time scale, with both FAC and $\mathrm{ClO}_{2}$, and $\mathrm{H}_{2} \mathrm{O}_{2}$ also reacts rapidly with $\mathrm{FAC}$ at the low $\mathrm{pH}$ of the anolyte liquor on a minute time scale [14]. These imply that $\mathrm{O}_{3}, \mathrm{ClO}_{2}$, and $\mathrm{H}_{2} \mathrm{O}_{2}$ cannot exist with FAC simultaneously for a long time in the OSG chlorine solution. Sobsey et al. (2000) [10] reported that the inactivation efficiencies of $C$. parvum oocysts by "mixed oxidants" were not consistent and predictable, and tended to decline over time. These observations can be interpreted to mean that the concentrations of other oxidants such as $\mathrm{O}_{3}, \mathrm{ClO}_{2}$, and $\mathrm{H}_{2} \mathrm{O}_{2}$ fluctuated very much, and they could remain in the system very briefly, if present. Usually, the OSG chlorine is stored on-site at water treatment plants for 1-3 $d$ [5, 7]. Under this condition, the 'other oxidants' may not be able to remain in the system, and it may not be appropriate to expect improved efficiency in disinfection by the OSG chlorine.

Another disinfection test was conducted under more realistic conditions of water treatment plants. When the $B$. subtilis spores were suspended in the sterilized sand-filtered water without any $\mathrm{pH}$ control, chlorine gas showed higher inactivation efficiency than two small-scale OSG chlorines at the same CT value (Table 1). Under uncontrolled $\mathrm{pH}$ conditions, the $\mathrm{pH}$ of chlorine gas-treated water was 0.2 to 0.6 lower than that of OSG chlorine-treated water at the same FAC dosage. This means that $\mathrm{HOCl}$, the stronger oxidant, could be higher in the chlorine gas-treated water, so the inactivation by chlorine gas could be more efficient than that by OSG chlorines.

From the two different test results above, it can be concluded that FAC is the primary oxidant in both "mixed oxidants" and OSG hypochlorite, and that the effects of other oxidants on the disinfection of suspended microorganisms are negligible. The disinfection by the OSG chlorine can be less effective than that by chlorine gas when OSG chlorines are used under common conditions in a typical water treatment plant unless the $\mathrm{pH}$ is adjusted by adding acids.

\subsection{Disinfection of Suspended Bacteria and Biofilm Control}

The inactivation of suspended bacteria and biofilm control by chlorine gas and the OSG chlorine ("mixed oxidants") were studied using the CDC biofilm reactors under continuous flow condition. Turbidity and TOC showed similar levels in the reactors added with two disinfectants during operation, whereas $\mathrm{pH}$ with the OSG chlorine was higher by 0.2 than that with chlorine gas (Table 2).

In inactivating suspended bacteria, chlorine gas was more efficient than OSG chlorine (Table 2). The hydraulic residence time of the CDC reactor was about $30 \mathrm{~min}$, and the CT values were 15 and $30 \mathrm{mg} \cdot \mathrm{min} / \mathrm{L}$ with FAC concentration of 0.5 and $1.0 \mathrm{mg} / \mathrm{L}$, respectively. Although the CT values were enough to inactivate HPC (heterotrophic plate count), suspended bacteria were detected in a few samples. Such might be caused by the insufficient contact time of the complete mixing-type reactors. Some bacteria in the influent might have been mixed completely as soon as inputted, and they might flow out of the reactors without sufficient contact time with the disinfectants. In addition, some bacteria with high resistance to chlorine could be detached from the biofilm and detected [26].

Biofilm control by chlorine gas and OSG chlorine was investigated by comparing the number of bacteria in the biofilm formed on PE and STS coupons (Fig. 3). There was little biofilm formation on the STS coupons except for some cases in the reactor of 0.5 $\mathrm{mg} / \mathrm{L}$ of OSG chlorine, so it was difficult to compare the effects on biofilm control by the disinfectants. The number of bacteria in the biofilm on PE coupons fluctuated with time but tended to increase until $30 \mathrm{~d}$ except for the $1.0 \mathrm{mg} / \mathrm{L}$ of OSG chlorine. After $70 \mathrm{~d}$, however, the number of bacteria in the biofilms on PE coupons decreased significantly. It could be attributed to the fact that biofilm formation could decrease with the decline of influent temperature (from 26 to $18^{\circ} \mathrm{C}$ ), whereas the bacteria in the biofilm on the coupons could be inactivated by long contact with the disinfectants.

OSG chlorine was more effective than chlorine gas in controlling biofilm on PE coupons although the concentration of FAC was slightly lower in reactors with OSG chlorine (Table 2). LeChevallier et al. (1988) [27] reported that $\mathrm{OCl}^{-}$could penetrate more effectively into biofilm than $\mathrm{HOCl}$ while it was less effective in inactivating suspended bacteria. Previous studies suggested that the inactivation of biofilm bacteria was closely related to the

Table 2. Water Quality Parameters and HPC Log Inactivation in CDC Biofilm Reactors

\begin{tabular}{|c|c|c|c|c|}
\hline & \multicolumn{2}{|c|}{ Chlorine gas } & \multicolumn{2}{|c|}{ OSG-A } \\
\hline & $0.5 \mathrm{mg} / \mathrm{L}$ & $1.0 \mathrm{mg} / \mathrm{L}$ & $0.5 \mathrm{mg} / \mathrm{L}$ & $1.0 \mathrm{mg} / \mathrm{L}$ \\
\hline Temperature $\left({ }^{\circ} \mathrm{C}\right)$ & \multicolumn{4}{|c|}{$17.8 \sim 25.8$ (avg. 21.6) } \\
\hline Turbidity (NTU) & $0.24 \pm 0.07$ & $0.24 \pm 0.06$ & $0.27 \pm 0.05$ & $0.27 \pm 0.05$ \\
\hline $\mathrm{pH}$ & $7.3 \pm 0.1$ & $7.3 \pm 0.1$ & $7.5 \pm 0.1$ & $7.5 \pm 0.1$ \\
\hline Residual chlorine (mg/L) & $0.56 \pm 0.11$ & $1.09 \pm 0.15$ & $0.49 \pm 0.12$ & $0.98 \pm 0.19$ \\
\hline TOC (mg/L) & $0.23 \pm 0.16$ & $0.22 \pm 0.13$ & $0.22 \pm 0.15$ & $0.22 \pm 0.15$ \\
\hline HPC log inactivation & $3.43 \pm 0.36$ & $4.25 \pm 0.45$ & $2.77 \pm 0.42$ & $3.45 \pm 0.68$ \\
\hline
\end{tabular}



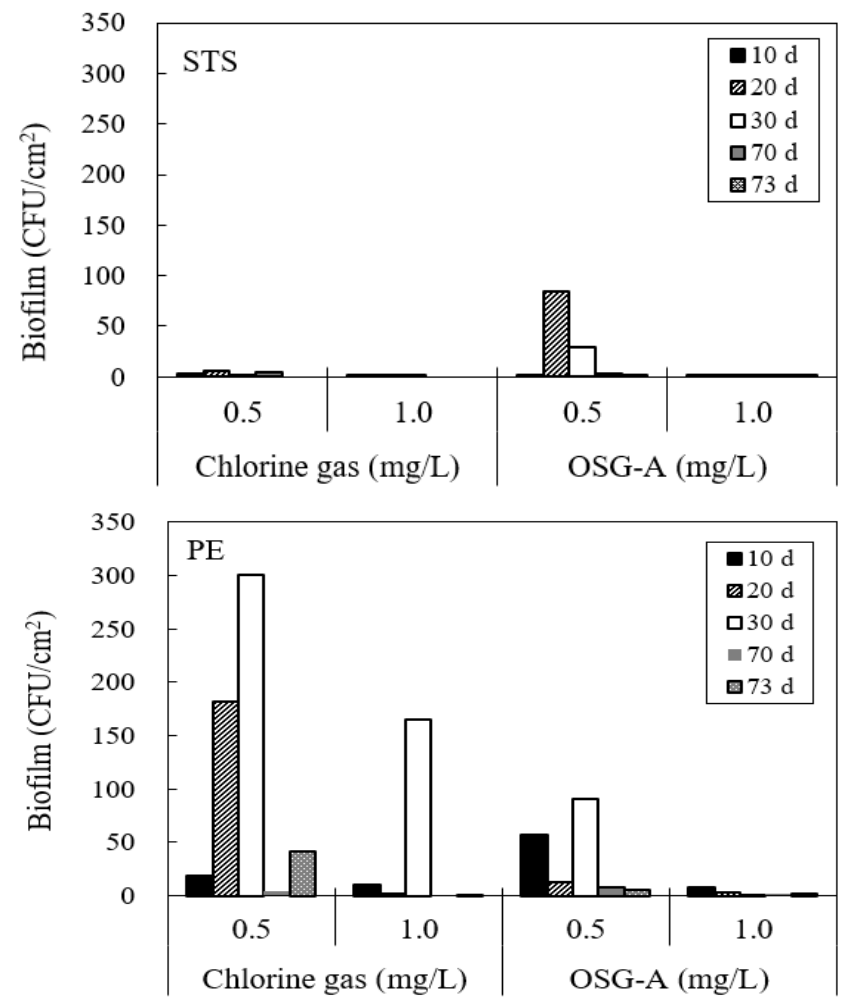

Fig. 3. Attached bacterial concentration in the biofilm on PE and STS coupons while maintaining residual chlorine in CDC biofilm reactors.

penetration of disinfectants into the biofilm, and disinfectants that were weakly reactive with constituents in the outer regions of the biofilm matrix could penetrate the biofilm more effectively $[27,28]$. Therefore, OSG chlorine with more $\mathrm{OCl}^{-}$can penetrate more effectively into the biofilm, and it can be more effective in controlling bacterial growth in the biofilm.

The number of biofilm bacteria differed by the material of coupon, i.e., the attached bacterial concentration in the biofilm was higher on PE coupons than on STS coupons with the same concentration of disinfectants. Many researchers reported that the characteristics of pipe material, including composition, roughness, and porosity, could affect bacterial attachment on the surface of the pipe system, and that they could be important factors in the attachment of bacteria [29-33]. Biofilm was reported to be formed more rapidly on the surface of plastic materials such as $\mathrm{PE}$ and polyvinyl chloride (PVC) than stainless steel, which could be attributed to the release of biodegradable compounds and nutrients from plastic pipes [29, 33].

\subsection{Disinfection By-Products Formation}

The DBPs formation by chlorine gas and two small-scale OSG chlorines was compared for sand-filtered water. The average concentrations of major DBPs by chlorine gas and OSG chlorines were at similar levels, i.e., THMs (23.4, 24.0 25.2 $\mu \mathrm{g} / \mathrm{L})$, HAAs (18.7, $19.9 \sim 20.3 \mu \mathrm{g} / \mathrm{L})$, and $\mathrm{CH}(7.8,7.3 \sim 7.9 \mu \mathrm{g} / \mathrm{L})$. However, the concentrations of some minor DBPs were lower with the OSG chlorines than with chlorine gas, i.e., HANs by $20.1 \sim 21.1 \%$ and HKs by
55.6 57.4\%. The concentrations of CP with three disinfectants were not significantly different in the range of less than $1 \mu \mathrm{g} / \mathrm{L}$ (Fig. 4).

To exclude the effect of the pre-chlorination process, DBPs formation in the processed glass fiber-filtered water with chlorine gas and five full-scale OSG chlorines was compared for THMs, HAAs, HANs, and $\mathrm{CH}$, which were detected in relatively high concentration. The concentrations of DBPs by the five OSG chlorines were not significantly different (relative standard deviation of less than 1.06\%). OSG chlorines formed less THMs, HAAs, HANs, and $\mathrm{CH}$ than chlorine gas by 8.8, 11.6, 39.7, and 39.9\%, respectively (Fig. 4).

The paired t-tests performed on all DBPs data from the tests with two small-scale and five full-scale OSG chlorines showed that the differences in DBPs concentrations between chlorine gas and "mixed oxidants"/OSG hypochlorite were not statistically significant at the 95\% confidence level except for HANs (paired t-test
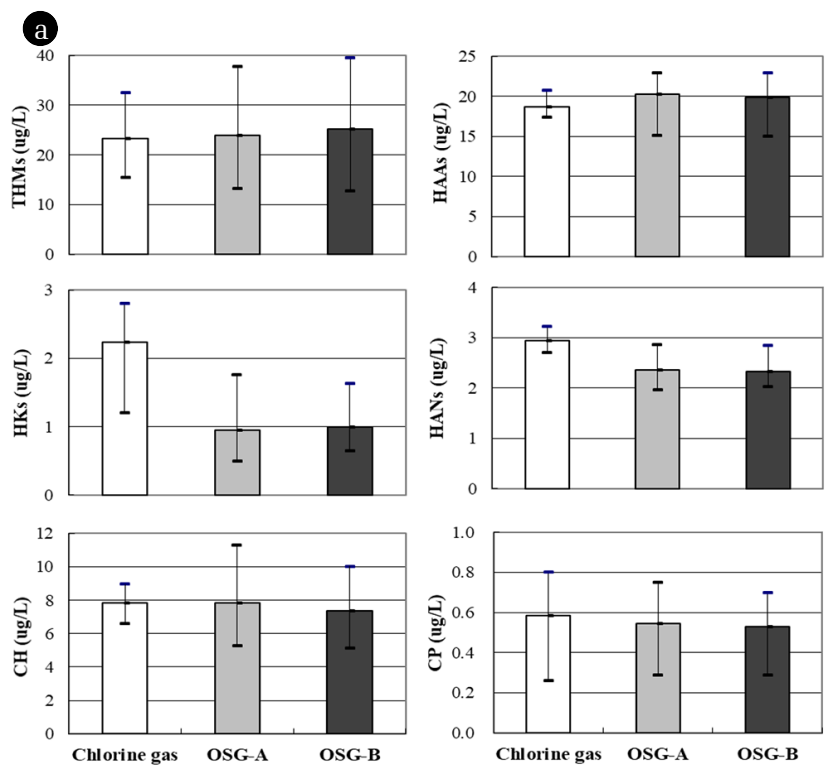

(b)
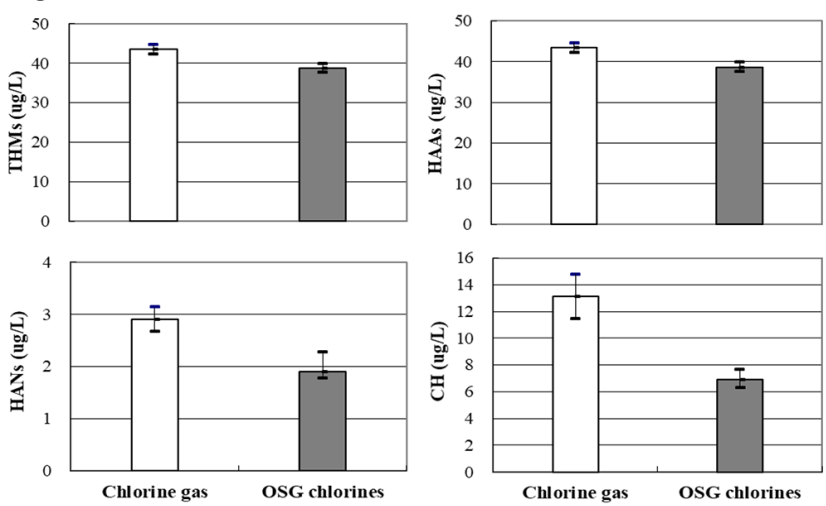

Fig. 4. DBPs formation by chlorine gas and two small-scale OSG chlorines for sand-filtered water (a) and by chlorine gas and five full-scale OSG chlorines for processed glass fiber-filtered water (b). The error bars indicate the maximum and minimum levels. 
for THMs, HAAs, HANs, HKs, CH, and CP, $\mathrm{p}=0.81 / 0.71,0.88 / 0.98$, 0.03/0.01, 0.09/0.10, 0.48/0.34, 0.40/0.32). CH showed a decreasing trend in many tests despite the high p-value. Further comparison tests will be needed to determine the effect of disinfectants on $\mathrm{CH}$ formation. Based on these results, a significant reduction in total DBPs formation cannot be expected by changing chlorine gas to OSG chlorines since the reducing effect of HANs by OSG chlorines will be negligible due to its low concentration.

Some reports showed a reduction in THMs and HAAs formation after replacing conventional chlorination with "mixed oxidants" in field studies and explained the reasons, including microflocculation effect, preferential action of nonchlorine oxidants, elimination of biofilm, and reduced dosage due to the improved chlorine residual $[4,13]$. Considering the batch test in the glass bottles with the same dose of disinfectants, only the preferential action of nonchlorine oxidants could be related to this study. However, in this study, chlorine gas and "mixed oxidants" did not show a significant difference in the formation of THMs and HAAs. Neither was there a significant difference in the formation of six DBPs between the "mixed oxidants" and the OSG hypochlorite (paired t-test, $\mathrm{p}=0.11 \sim 0.70$ ). This could be attributed to the very little production of other oxidants such as $\mathrm{O}_{3}, \mathrm{ClO}_{2}$, and $\mathrm{H}_{2} \mathrm{O}_{2}$ in "mixed oxidants" or decomposition of those oxidants during storage. The reducing DBP precursors by oxidants other than FAC in "mixed oxidants" may be negligible.

\subsection{Chlorine Demand and Decay Rate}

For the processed glass fiber-filtered water, chlorine demand with chlorine gas $(1.94 \mathrm{mg} / \mathrm{L})$ was higher than that with five full-scale OSG chlorines (1.47 1.58 mg/L). The chlorine demand of "mixed oxidants" was $1.53 \mathrm{mg} / \mathrm{L}$, which was a similar level to that of other OSG hypochlorites (Fig. S3). The higher chlorine demand with chlorine gas may be explained as the reductive compounds could react more with chlorine gas due to the higher concentration of $\mathrm{HOCl}$.

$2 \mathrm{mg} / \mathrm{L}$ as FAC of chlorine gas and two small-scale OSG chlorines were added to the sand-filtered water, and the concentrations of residual FAC were measured by time. The concentration of residual FAC of the OSG chlorines tended to be higher than that of chlorine gas (Fig. S4), and chlorine demand with the OSG chlorines decreased by about $0.1 \mathrm{mg} / \mathrm{L}$ over chlorine gas (Table 3). Such difference in chlorine demand was mainly attributed to the higher 2 h-chlorine demand of chlorine gas. The initial chlorine demand is caused by inorganic reducing compounds such as $\mathrm{Fe}^{2+}, \mathrm{Mn}^{2+}$, and $\mathrm{NO}_{2}{ }^{-}$ in water, and it can vary in water quality $[15,34]$. In the sample with TOC $1.07 \mathrm{mg} / \mathrm{L}$, the $2 \mathrm{~h}$-chlorine demand of chlorine gas was very low and at a similar level to that of OSG chlorines. Thus, the 48 h-chlorine demands were not significantly different among three disinfectants.

The rapid chlorine decay rates $\left(K_{1}\right)$ with the OSG chlorines tended to be lower than those with chlorine gas, whereas the slow chlorine decay rates $\left(\mathrm{K}_{2}\right)$ did not show a significant difference by three disinfectants (paired t-test, $\mathrm{p}>0.42$ ) (Table 3). This implies that the consumption of residual FAC may be controlled mainly by the rapid reaction of the early stage. As the rapid reaction will be completed within a clear well when disinfectant is added in a water treatment plant, the concentration of residual FAC in the distribution system may not be significantly different by disinfectants as long as the FAC concentration of the effluent from the clear well is kept constant.

\subsection{Volatility}

Volatility experiments were carried out under $\mathrm{pH} 7.5$, below 5 , and over 10 at room temperature for $28 \mathrm{~h}$. Samples with $\mathrm{pH} 7.5$ and below $\mathrm{pH} 5$ showed an insignificant change of $\mathrm{pH}( \pm 0.05)$, but the $\mathrm{pH}$ of the sample over $\mathrm{pH} 10$ decreased to $\mathrm{pH} 9$ due to the dissolution of $\mathrm{CO}_{2}$ for a $28 \mathrm{~h}$ residence time. $\mathrm{OCl}^{-}$is the main FAC species at $\mathrm{pH} 9$, and the difference in percent of $\mathrm{OCl}^{-}$between $\mathrm{pH} 9$ and $\mathrm{pH} 10$ is less than about $3 \%$ above $20^{\circ} \mathrm{C}$ [2]; this means that there was no significant change in the ratio of $\mathrm{HOCl} / \mathrm{OCl}^{-}$ in all samples during the test.

The volatility of chlorine gas and OSG chlorine did not show a significant difference. The difference in the reduced FAC concentrations (volatility) in the two disinfectant-treated samples at the same $\mathrm{pH}$ was within $0.06 \mathrm{mg} / \mathrm{L}$. Note, however, that there was a significant difference in volatility with $\mathrm{pH}$ (Fig. 5). The volatility of both disinfectants was highest below $\mathrm{pH} 5$ and lowest over $\mathrm{pH}$ 10. Hypochlorite ion $\left(\mathrm{OCl}^{-}\right)$is virtually non-volatile while hypochlorous acid ( $\mathrm{HOCl})$ and molecular chlorine $\left(\mathrm{Cl}_{2}\right)$ are volatile [6, 35]. Therefore, the volatility of FAC can decrease with increasing $\mathrm{pH}$ due to the increase of non-volatile hypochlorite ion [6]. This suggests that the volatility of FAC in the chlorine gas-treated water with higher $\mathrm{HOCl}$ is higher than that in the OSG chlorine-treated water. This observation can be one of the possible explanations

Table 3. Chlorine Demand and Chlorine Decay Rate of Chlorine Gas and Two Small-Scale OSG Chlorines in The Sand-Filtered Water at $25^{\circ} \mathrm{C}$. $\left(\mathrm{K}_{1}\right.$ : rapid decay rate in $6 \mathrm{~h}, \mathrm{~K}_{2}$ : slow decay rate after $\left.6 \mathrm{~h}\right)$

\begin{tabular}{|c|c|c|c|c|c|c|c|c|c|c|c|c|c|c|c|}
\hline \multirow{3}{*}{$\begin{array}{l}\text { TOC } \\
(\mathrm{mg} / \mathrm{L})\end{array}$} & \multicolumn{5}{|c|}{ Chlorine gas } & \multicolumn{5}{|c|}{ OSG-A } & \multicolumn{5}{|c|}{ OSG-B } \\
\hline & \multicolumn{3}{|c|}{$\begin{array}{c}\text { Chlorine demand } \\
(\mathrm{mg} / \mathrm{L})\end{array}$} & \multicolumn{2}{|c|}{$\begin{array}{c}\text { Decay rate }\left(h^{-1}\right) \\
\left(R^{2}\right)\end{array}$} & \multicolumn{3}{|c|}{$\begin{array}{l}\text { Chlorine demand } \\
(\mathrm{mg} / \mathrm{L})\end{array}$} & \multicolumn{2}{|c|}{$\begin{array}{c}\text { Decay rate }\left(h^{-1}\right) \\
\left(\mathbf{R}^{2}\right)\end{array}$} & \multicolumn{3}{|c|}{$\begin{array}{c}\text { Chlorine demand } \\
\text { (mg/L) }\end{array}$} & \multicolumn{2}{|c|}{$\begin{array}{c}\text { Decay rate }\left(h^{-1}\right) \\
\left(R^{2}\right)\end{array}$} \\
\hline & $2 \mathrm{~h}$ & $24 \mathrm{~h}$ & $48 \mathrm{~h}$ & $K_{1}$ & $\mathbf{K}_{2}$ & $2 \mathrm{~h}$ & $24 \mathrm{~h}$ & $48 \mathrm{~h}$ & $K_{1}$ & $\mathbf{K}_{2}$ & $2 \mathrm{~h}$ & $24 \mathrm{~h}$ & $48 \mathrm{~h}$ & $K_{1}$ & $\mathbf{K}_{2}$ \\
\hline 0.79 & 0.26 & 0.67 & 0.86 & $\begin{array}{l}-0.045 \\
(0.89)\end{array}$ & $\begin{array}{l}-0.006 \\
(0.91)\end{array}$ & - & 0.59 & 0.75 & $\begin{array}{r}-0.030 \\
(0.96)\end{array}$ & $\begin{array}{l}-0.006 \\
(0.91)\end{array}$ & - & 0.53 & 0.71 & $\begin{array}{l}-0.028 \\
(0.88)\end{array}$ & $\begin{array}{l}-0.006 \\
(0.90)\end{array}$ \\
\hline 0.86 & 0.41 & 0.79 & 0.97 & - & $\begin{array}{l}-0.006 \\
(1.00)\end{array}$ & 0.33 & 0.69 & 0.89 & - & $\begin{array}{l}-0.006 \\
(0.89)\end{array}$ & 0.31 & 0.70 & 0.90 & - & $\begin{array}{l}-0.005 \\
(0.90)\end{array}$ \\
\hline 1.07 & 0.08 & 0.61 & 0.79 & $\begin{array}{c}-0.030 \\
(0.97)\end{array}$ & $\begin{array}{c}-0.006 \\
(0.97)\end{array}$ & 0.05 & 0.53 & 0.77 & $\begin{array}{c}-0.018 \\
(0.99)\end{array}$ & $\begin{array}{c}-0.006 \\
(0.91)\end{array}$ & 0.12 & 0.59 & 0.79 & $\begin{array}{c}-0.029 \\
(1.00)\end{array}$ & $\begin{array}{r}-0.006 \\
(0.96)\end{array}$ \\
\hline
\end{tabular}




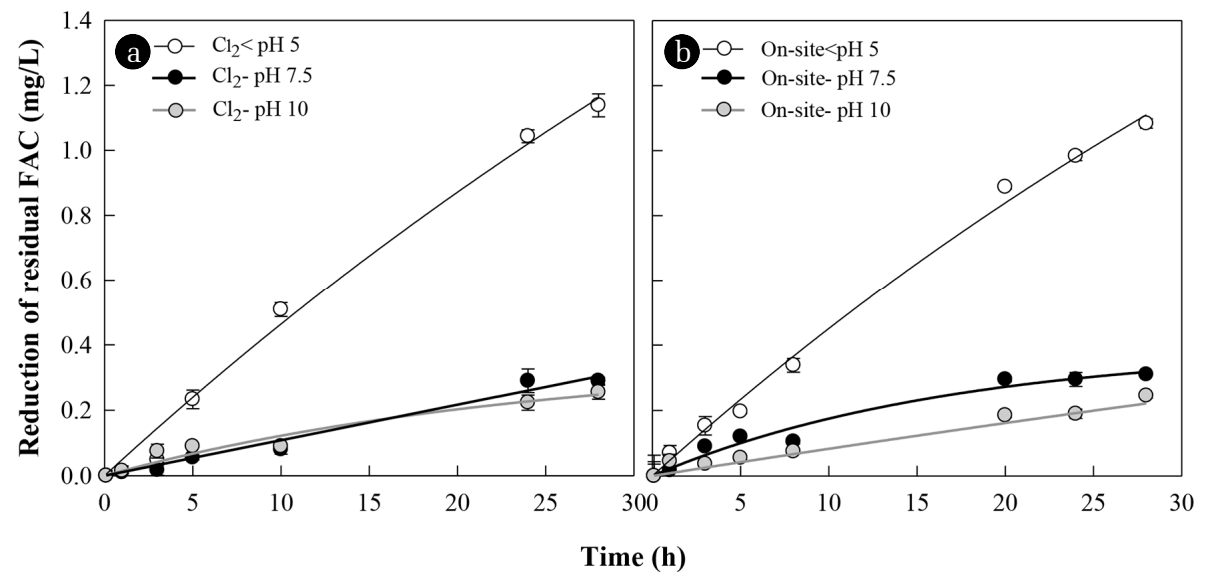

Fig. 5. Volatility of chlorine gas (a) and OSG chlorine (b) with time and $\mathrm{pH}$.

for the high chlorinous odor in the chlorine gas-treated water than OSG chlorine-treated water.

\section{Conclusions}

Both chlorine gas and OSG chlorine use the oxidizing power of $\mathrm{HOCl}$ and $\mathrm{OCl}^{-}$for the disinfection of microorganisms and oxidation of organic matter in drinking water treatment. However, OSG chlorine increases the $\mathrm{pH}$ of the treated water while chlorine gas decreases the $\mathrm{pH}$ with the same concentration of disinfectant as FAC. Since the $\mathrm{pH}$ is one of the main factors determining oxidizing power, reactivity, and volatility of $\mathrm{FAC}$, OSG chlorine with more $\mathrm{OCl}^{-}$ at higher $\mathrm{pH}$ can be less oxidative and reactive. As a result, OSG chlorine can be less effective in disinfecting suspended microorganisms and removing organic compounds. However, OSG chlorine can be a more effective secondary disinfectant as it can remain longer in the distribution system and control biofilm more effectively due to its higher ability to penetrate the biofilm. In addition, the low volatility of FAC in the OSG chlorine-treated water may help reduce the chlorinous odor in drinking water.

Both OSG chlorines produced by the electrolysis of brine, i.e., sodium hypochlorite and "mixed oxidants", had similar effects on disinfection, DBP formation, and chlorine decay rate. A significant additional synergy effect by oxidants other than FAC in the "mixed oxidants" cannot be expected in a typical water treatment plant as other oxidants cannot remain in the storage tank for a long time although they can be generated during electrolysis.

\section{Acknowledgment}

This study was conducted as a part of the research project of the Seoul Water Institute [36, 37].

\section{Author Contributions}

Y. C (Researcher) designed this research work, drafted the manu- script, operated the OSG systems, and conducted disinfection, chlorine decay, and volatility experiments. S.H.B (Researcher) and S.E.K.(Researcher) conducted DBP formation experiments and data analysis. H.J.J. (Researcher) operated biofilm reactors and conducted biofilm disinfection experiments. Y.C (Director) supervised this research work and revised the manuscript.

\section{References}

1. Shah J, Qureshi N. Chlorine gas vs. sodium hypochlorite: What's the best option? Opflow. 2008;34:24-27.

2. White GC. Handbook of Chlorination and Alternative Disinfectants. 4th ed. New York (NY): John Wiley \& Sons, Inc; 1999. p 167-287, 331-536.

3. Rowe J. Understanding sodium hypochlorite [Web Magazine] tpo; 2013. Available from: http://tpomag.com/editorial/2013/ 12/understanding_sodium_hypochlorite_wso.

4. Bradford WL. The Differences between On-Site Generated Mixed-Oxidant Solution and Sodium Hypochlorite. (aka the Master Features Summary). 2011.

5. Boal AK. On-Site Generation of Disinfectants. Tech. Brief. 2009;9:1-4.

6. American Water Works Association (AWWA). Water quality and treatment: A handbook of community water supplies. 5th ed. New York (NY): McGraw-Hill; 1999. p 12.1-12.51, 14.1-14.60.

7. Casson LW, Bess JW. On-site sodium hypochlorite generation. In Water Environment Federation's 79th Annual Technical Exhibition \& Conference (WEFTEC.06); 21-25 October 2006; Dallas, TX, p. 6335-6352.

8. Geldenhuys JC. The application and efficiency of 'Mixed oxidants' for the treatment of drinking water. Pretoria: Water Research Commission (WRC). (WRC Report No. 832/1/00)

9. Rivera S, Matousek R. On-site generation of hypochlorite. American Water Works Association; 2015. Chapter 1, Overview; p. 1-9. (AWWA Manual M65).

10. Sobsey MD, Kase JA, Anderson ME, Casteel MJ, Likirdopulos C, Sickbert-Bennett E. Inactivation of Cryptosporidium parvum oocysts and other waterborne microbes by oxidants generated 
electrochemically from sodium chloride from portable pen and bench scale systems. In: American Water Works Association. Water Quality Technology Conference; 2000; Denver (CO).

11. Venczel LV, Arrowood M, Hurd M, Sobsey MD. Inactivation of Cryptosporidium parvum oocysts and Clostridium perfringens spores by a mixed-oxidant disinfectant and by free chlorine. Appl. Environ. Microbiol. 1997;63:1598-1601.

12. Son H, Cho M, Chung H, Choi S, Yoon J. Bactericidal activity of mixed oxidants: comparison with free chlorine. J. Ind. Eng. Chem. 2004;10:705-709.

13. Hamm B. DBP reduction using mixed oxidants generated on site. J. AWWA. 2002;94:49-53.

14. Gordon G, Bolden R, Emmert G. Measuring oxidant species in electrolyzed salt brine solutions. J. AWWA. 2002;94:111-120.

15. Deborde M, von Gunten U. Reactions of chlorine with inorganic and organic compounds during water treatment-Kinetics and mechanisms: A critical review. Water Res. 2008;42:13-51.

16. USEPA. Ultraviolet disinfection guidance manual for the final long term 2 enhanced surface water treatment rule. Pennsylvania: USEPA; 2006. (EPA 815-R-06-007).

17. Munch JW, editor. Method 524.2 Measurement of purgeable organic compounds in water by capillary column gas chromatography/mass spectrometry. Cincinnati (OH): USEPA; 1995.

18. Domino MM, Pepich BV, Munch DJ, Fair PS, Xie Y. Method 552.3 Determination of haloacetic acids and dalapon in drinking water by liquid-liquid microextraction, derivatization, and gas chromatography with electron capture detection. Cincinnati $(\mathrm{OH})$ : USEPA; 2003. (EPA 815-B-03-002).

19. Munch DJ, Hautman DP. Method 551.1 Determination of chlorination disinfection byproducts, chlorinated solvents, and halogenated pesticides/herbicides in drinking water by liquid-liquid extraction and gas chromatography with electron-capture detection. Cincinnati (OH); USEPA; 1995.

20. Vasconcelos JJ, Rossman LA, Grayman WM, Boulos PF, Clark RM. Kinetics of chlorine decay. J. AWWA. 1997;89:54-65.

21. Lee KH, Lim JL, Lee DJ, Kim SS, Ahn HW. Evaluation of disinfection characteristics of mixed oxidants produced by electro-chemical method. J. Korean Soc. Water Wastewater. 2005;19: 625-631.

22. Son H, Cho M, Kim J, Oh B, Chung H, Yoon J. Enhanced disinfection efficiency of mechanically mixed oxidants with free chlorine. Water Res. 2005;39:721-727.

23. Jung YJ, Oh BS, Kang JW, Page MA, Phillips MJ, Mariňas BJ. Control of disinfection and halogenated disinfection byproducts by the electrochemical process. Water Sci. Technol. 2007;55:
213-219.

24. Bergmann H, Koparal S. The formation of chlorine dioxide in the electrochemical treatment of drinking water for disinfection. Electrochim. Acta. 2005;50:5218-5228.

25. Tien TT, Luu TL. Electrooxidation of tannery wastewater with continuous flow system: Role of electrode materials. Environ Eng Res. 2020;25:324-334.

26. Choi Y, Cha Y, Kim B. Characteristics of bacterial communities in biological filters of full-scale drinking water treatment plants. J. Microbiol. Biotechnol. 2019;29:91-104.

27. LeChevallier MW, Cawthon CD, Lee RG. Inactivation of biofilm bacteria. Appl. Environ. Microbiol. 1988;54:2492-2499.

28. Stewart PS, Rayner J, Roe F, Rees WM. Biofilm penetration and disinfection efficacy of alkaline hypochlorite and chlorosulfamates. J. Appl. Microbiol. 2001;91:525-532.

29. Jang HJ, Choi YJ, Ka JO. Effects of diverse water pipe materials on bacterial communities and water quality in the annular reactor. J. Microbiol. Biotechnol. 2011;21:115-123.

30. Pedersen K. Biofilm development on stainless steel and PVC surfaces in drinking water. Water Res. 1990;24:239-243.

31. Schwartz T, Hoffmann S, Obst U. Formation and bacterial composition of young, natural biofilms obtained from public bank-filtered drinking water systems. Water Res. 1998;32: 2787-2797.

32. Niquette P, Servais P, Savoir R. Impacts of pipe materials on densities of fixed bacterial biomass in a drinking water distribution system. Water Res. 2000;34:1952-1956.

33. Rogers J, Dowsett AB, Dennis PJ, Lee JV, Keevil CW. Influence of plumbing materials on biofilm formation and growth of Legionella pneumophila in potable water systems. Appl. Environ. Microbiol. 1994;60:1842-1851.

34. Jollley RL, Carpenter JH. Aqueous chemistry of chlorine: Chemistry, analysis, and environmental fate of reactive oxidant species. Tennessee: OAK RIDGE NATIONAL LABORATORY; 1982. ORNL/TM-7788.

35. McCoy WF, Blatchley ER, Johnson RW. Hypohalous acid and haloamine flashoff in industrial evaporative cooling systems. In: Cooling Tower Institute Annual Meeting; 5-7 February 1990; Houston, Texas.

36. Waterworks Research Institute. Comparative study of chlorine gas and electrolytic disinfectant. Seoul: 2009 Waterworks Research Report; 2010. p. 131-180.

37. Waterworks Research Institute. Study on biofilm reduction measures in drinking water distribution systems. Seoul: 2009 Waterworks Research Report; 2010. p. 381-488. 